\title{
The relationship between m-banking service quality and loyalty: evidence in Indonesian Islamic Banking
}

\author{
Rizaldi Yusfiarto \\ Department of Islamic Finance Management, Faculty of Islamic Economics \\ and Business, UIN Sunan Kalijaga Yogyakarta, Sleman, Indonesia \\ Corresponding author: rizaldi.yusfiarto@uin-suka.ac.id
}

\author{
Article history \\ Received, 30 March 2021 \\ Revised 1, 12 May 2021 \\ Revised 2, 25 May 2021 \\ Accepted, 31 May 2021
}

\begin{abstract}
Purpose: This study generally aims to comprehensively examine the effect of mobile banking service quality on creating customer loyalty in Islamic banking. In particular, this research uses the E-S-Qual instrument to verify service quality in mobile banking and uses one mediation variable, namely e-customer satisfaction.
\end{abstract}

Methodology: This study amounted to 273 Islamic banking customers. The total participants are divided into several categories such as; gender, occupation, domicile, and Islamic bank used. The data obtained were analyzed using the Structural Equation Modeling (SEM) approach. This study also uses a secondorder perspective (reflective-reflective) SEM on the E-S-Qual variable (efficiency, fulfillment, system availability, and privacy), then the approach used refers to the repeated indicators.

Findings: The higher mobile banking service quality has implications for customer loyalty, both attitude and behavior. It happens when the customer is satisfied with the quality of the system displayed. This satisfaction can be achieved if the dimensions of quality that are characteristic of the system can be presented by Islamic banking.

Originality: This study underscores the dimensions of efficiency and system availability as keys to mobile banking service quality. Efficiency refers to how the ease, accessibility, and speed provided by the system can facilitate transactions and other functions. Furthermore, system availability refers to how the platforms function properly in relation to technical constraints that may arise, as well as attachment to functions that strengthen processes in the business of Islamic banking customers.

Keyword: M-Banking Service Quality, E-Satisfaction, Attitudinal Loyalty, Behavioural Loyalty

Cite this article:

Yusfiarto, R (2021). The Relationship between M-Banking Service Quality and Loyalty: Evidence in Indonesian Islamic Banking. Asian Joumal of Islamic Management, 3 (1), 23-33. https://doi.org/10.1108/AJIM.vol3.iss1.art3

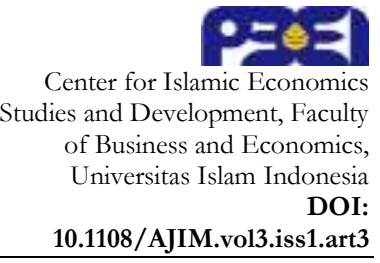

\section{Introduction}

Technological advances have restructured the global banking industry, which has affected the design and financial services provided to customers. The foundation of this change focuses on increasing customer usability, perception, and encouraging consumer loyalty at alternative channel points (Sharma \& Malviya, 2014). The speed of change also affects banking customer behavior, including Islamic banking (Raza et al., 2019). The usability of smartphones for everything changes how customers perceive the services and products offered by banking (Nisha, 2016). In the context of mobile-based financial services, customers tend to evaluate between banks by making trade-offs of trust, service satisfaction, relationships, and the economy, as well as perceived conveniences that drive customer effectiveness (Riza, 2019; Sachdev \& Verma, 2004). 
Currently, smartphone-based services such as mobile banking (m-banking), both conventional and Islamic banking, are in great demand by customers. These services offer various advantages that can be utilized, such as cost efficiency and transaction time effectiveness (Arcand et al., 2017; Baabdullah et al., 2019; Samsudeen et al., 2020). Furthermore, the significance of using smartphones encourages a shift in customer behavior from using cash transactions to $\mathrm{m}$-banking (Fall et al., 2020; Liébana-Cabanillas et al., 2015). M-banking itself is an internet-based banking service and uses smartphones as a medium, where transaction mobility is the main feature (Baabdullah et al., 2019; Mohd Thas Thaker et al., 2019; Shankar \& Rishi, 2020). In Indonesia, data shows that $\mathrm{m}$-banking users reached $56 \%$ of the total population in 2019 . This report can be a benchmark that the potential for digital banking services is still huge (Bank Indonesia, 2019). Based on this explanation, Islamic banking should evaluate electronic services provided to customers; smartphone-based services such as m-banking deserve special attention as a market penetration strategy through excellent service.

Several findings have focused on electronic service quality on banking customer loyalty (Amin, 2016; Cahaya \& Siswanti, 2020). However, these findings only focus on internet banking and the antecedent factors of customer attitudes towards mobile banking adoption behavior (Raza et al., 2020; Shaikh \& Karjaluoto, 2015; Riza \& Hafizi, 2019). Therefore, it is crucial to carry out an in-depth investigation of $\mathrm{m}$-banking from a relationship marketing perspective (Arcand et al., 2017; Tumewah et al., 2020). More specifically, it is imperative when considering the impact of the quality of mobile banking services on the emergence of banking customer satisfaction and loyalty (Jun \& Cai, 2001). Until now, findings in previous studies that have predicted the impact of electronic service quality on customer satisfaction have been carried out (Sagib \& Zapan, 2014; Thakur \& Srivastava, 2014; Yuan et al., 2016). This study seeks to fill this gap with Islamic banks as objects to strengthen further the findings regarding the impact of mobile-based service quality on two relational variables such as customer satisfaction and loyalty.

Regarding the above explanation, this study generally aims to comprehensively examine the effect of mobile banking service quality on creating customer loyalty in Islamic banking, especially in Indonesia. In particular, this research uses the E-S-Qual instrument to verify service quality in mobile banking and uses one mediation variable, namely e-customer satisfaction. Based on the research objectives, the research questions can be described as follows; (1) how the influence of mobile banking service quality (using the ES-Qual instrument) is related to building customer loyalty in terms of both attitude and behavior, (2) how does electronic satisfaction influence in building customer loyalty both attitude and behavior (3) whether e-satisfaction can significantly mediate the relationship between mobile banking service quality (using the ES-Qual instrument) and the creation of customer loyalty, both attitude and behavior.

\section{Literature Review and Hypotheses Development}

\section{Loyalty}

Consumer loyalty refers to aspects of attitude and behavior. Consumer loyalty focuses on repeat buying behavior based on a combination of positive and negative traits in the transaction process. From this understanding, it can be interpreted that brand loyalty is obtained because of a combination of satisfaction and complaints (Oliver, 1999). Loyalty models have become an important focus in the foundation of e-business because of crucial competitive factors (Gefen, 2002; Srinivasan et al., 2002; Swaminathan et al., 2018). In both practical and theoretical contexts, building customer loyalty is one of the keys to a successful strategy, as well as the need for value creation in an electronically based company. It causes a real-time evaluation of services and products due to the reduction of restrictions such as physical restrictions, time, place (Kannan et al., 2002; Sathiyavany \& Shivany, 2018). For this reason, banks need to provide quality e-banking services to build superior loyalty, so that it has an impact on increasing their profitability (Chowdhury et al., 2017; Fragata \& Moustakas, 2013). 


\section{E-Service Quality}

In the face-to-face context, SERVQUAL has been adopted for the needs of measuring the quality of services obtained by banking customers (Banerjee \& Sah, 2012; Omoregie et al., 2019). With the advancement of internet use, the instruments in SERVQUAL have been contextualized into a service quality measurement tool with an electronic perspective (e-SQ). This instrument is divided into several core dimensions to measure customer perceptions regarding the platforms' ease and speed: efficiency, fulfillment, system availability, and privacy (Parasuraman et al., 2005). Several studies have shown its significance, and most studies state that the e-SERVQUAL dimension is a determining factor for electronic technology-based service approval (Anderson \& Srinivasan, 2003; Ariff et al., 2014; Nisha, 2016). Completing this statement, the quality of electronic service is closely related to how satisfaction is created. With the presence of an intermediary for satisfaction, customer loyalty can immediately emerge from the bottom of the customer's heart (Arcand et al., 2017; Saibil, 2020; Sathiyavany \& Shivany, 2018). Specific to the E-S-Qual dimension, previous research has underlined that this dimension should be an important priority to measure how much the quality of electronicbased services has an impact on loyalty (Asgari et al., 2014; Yang \& Tsai, 2007), especially in the mbanking method (Nisha, 2016). Based on the description, the hypothesis is offered as follows:

H1: M-Banking Quality (E-S-Qual) has a positive and significant direct effect on Islamic Banking Attitudinal Loyalty

H2: M-Banking Quality (E-S-Qual) has a positive and significant direct effect on Islamic Banking Behavioral Loyalty

H3: E-Satisfaction mediates the relationship between M-Banking Quality (E-S-Qual) and Islamic Banking Attitudinal Loyalty

H4: E-Satisfaction mediates the relationship between M-Banking Quality (E-S-Qual) and Islamic Banking Behavioral Loyalty.

\section{E-Satisfaction}

Based on value-percept disparity theory, customer satisfaction includes the condition and evaluation of customer decisions that meet the highest expectations (Westbrook \& Reilly, 1983). Furthermore, Fraering \& Minor (2013) underlines satisfaction with feelings of pleasure for actions that evaluate performance with their expectations. Assessment of satisfaction from an electronic perspective, Anderson \& Srinivasan (2003) describes assessment as an evaluation of customer purchasing performance for products transacted through electronic commerce. Previous findings have shown that banking customers always evaluate their satisfaction and can directly transfer their purchases to other financial service companies (Aisyah, 2018; Dandis \& Wright, 2020; Sathiyavany \& Shivany, 2018). Furthermore, satisfaction with electronics is very close to the electronic services provided before. The sheer number of alternatives in financial services makes customers emphasize the value of the quality of service they get. The stronger the perception of the value obtained from electronic banking services, customer behavior will lead to maximum satisfaction (Quan, 2010; Sundaram et al., 2017; Zavareh et al., 2012). Based on the description, the hypothesis is offered as follows:

H5: M-Banking Quality (E-S-Qual) has a positive and significant direct effect on Islamic Banking E-Satisfaction

H6: Customer E-Satisfaction has a positive and significant direct effect on Islamic Banking Attitudinal Loyalty

H7: Customer E-Satisfaction has a positive and significant direct effect on Islamic Banking Behavioral Loyalty

\section{Methods}

\section{Data}

The research data was collected using databases of Islamic banks, communities, and Islamic institutions. Furthermore, the questionnaire was distributed using online media and utilizing the 
google form media as a questionnaire tool. Data were analyzed using purposive sampling technique with the following criteria: (a) Indonesian Islamic banking customers; (B) have been using mobile banking for at least one year. Based on these criteria, the sample in this study amounted to 273 Islamic banking customers. The profile of the customers is divided into several categories such as; gender, occupation, domicile, and Islamic bank used (see Table 1). Overall, respondents are dominated by gender (55.6 percent are male), occupation (entrepreneurs and professional is 57.1 percent), domicile by province (Central Java and East Java is 32.97 percent), Islamic banks are used (Bank Syariah Indonesia is 75.82 percent).

Table 1. Respondent Profile

\begin{tabular}{llcc}
\hline & Category & Number of Respondents & Percentage \\
\hline Gender & Man & 152 & $55.68 \%$ \\
\multirow{5}{*}{ Occupation } & Women & 122 & $44.69 \%$ \\
& Student College & 117 & $42.86 \%$ \\
Domicile by Province & 156 & $57.14 \%$ \\
& Entrepreneurs \& Professional & 80 & $29.30 \%$ \\
& DI Yogyakarta & 90 & $32.97 \%$ \\
& Central Java and East Java & 56 & $20.51 \%$ \\
& West Java and Lampung & 47 & $17.22 \%$ \\
& DKI jakarta and banten & 207 & $75.82 \%$ \\
& Bank Syariah Indonesia & 45 & $16.48 \%$ \\
& Bank Muamalat & 21 & $7.69 \%$ \\
\hline
\end{tabular}

Source: Author research, 2020

\section{Data Analysis}

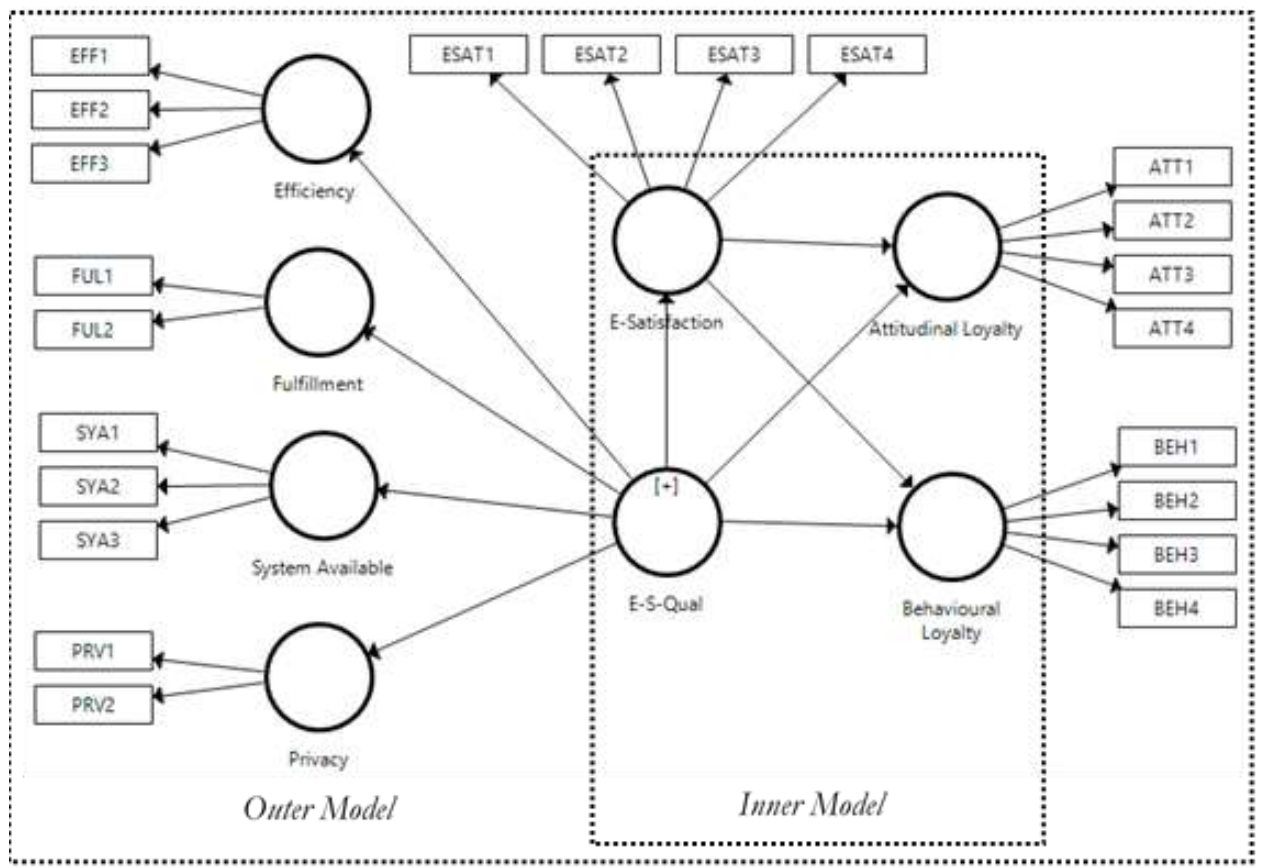

Source: Author research, 2020

Figure 1. Conceptual Path Diagram SEM

This research was conducted using Structural Equation Modeling (SEM), which was carried out through the Smart-PLS 3rd edition software. Structural Equation Modeling (SEM) is a multivariate technique that combines aspects of factor analysis and multiple regression that allows researchers to simultaneously analyze a series of interrelated dependency relationships between the measured variable and the latent variable and among several latent variables (Hair et al., 2010). SEM prioritizes 
technical analysis which is more challenging. That is, research using SEM aims to test whether a particular model is valid rather than the use of a particular model that is suitable or not, whereas SEM analysis often involves elements used to explain (Anwar et al., 2018). SEM-PLS is used because of the complexity of the model in this study and the tendency of the data to be not normally distributed, so that hypothesis testing can be adequately analyzed (Hair 2014). Finally, this study uses a second-order perspective (reflective-reflective) SEM on the E-S-Qual variable (efficiency, fulfillment, system availability, and privacy), then the approach used refers to the repeated indicators recommended by Hair et al. (2014). For that, the conceptual model in this study is presented in Figure 1.

\section{Results}

\section{Measurement Models}

Before entering into inner model testing, it is necessary to test the outer model. The first test is the multicollinearity test of data using the value of variance inflation factors (VIF). The cut-off value used is the VIF value $<5$, following the recommendation from Hair et al. (2014). The test output shows that the VIF value is in the range of 1.463 to 3.505 . It can be concluded that there is no multicollinearity problem. Furthermore, the outer loadings test is carried out to identify the weights in the data. The output shows that the overall outer loading value is above 0.70 , as suggested by (Hair et al., 2014). It can be concluded that the data is at high convergent validity.

Table 2. Measurement Model Results

\begin{tabular}{lcccccccc}
\hline \multicolumn{1}{c}{ Latent Variabel } & Manifest Variable & VIF & Loadings & $\alpha$ & rho_A & CR & AVE & $\sqrt{\text { AVE }}$ \\
\hline Efficiency & EFF1 & 1.878 & $0.834^{* * *}$ & 0.870 & 0.870 & 0.870 & 0.690 & 0.831 \\
& EFF2 & 2.740 & $0.824^{* * *}$ & & & & & \\
Fulfillment & EFF3 & 2.971 & $0.835^{* * *}$ & & & & & \\
Privacy & FUL1 & 2.176 & $0.885^{* * *}$ & 0.847 & 0.850 & 0.848 & 0.737 & 0.858 \\
& FUL2 & 2.176 & $0.830^{* * *}$ & & & & & \\
System Availability & PRV1 & 2.087 & $0.846^{* * *}$ & 0.838 & 0.838 & 0.838 & 0.722 & 0.850 \\
& PRV2 & 2.087 & $0.853^{* * *}$ & & & & & \\
E-S-Qual & SYA1 & 1.748 & $0.768^{* * *}$ & 0.842 & 0.845 & 0.844 & 0.643 & 0.802 \\
& SYA2 & 2.611 & $0.829^{* * *}$ & & & & & \\
& SYA3 & 2.187 & $0.808^{* * *}$ & & & & & \\
& EFF & 2.530 & $0.942^{* * *}$ & 0.925 & 0.926 & 0.925 & 0.553 & 0.744 \\
E-Satisfaction & FUL & 2.176 & $0.948^{* * *}$ & & & & & \\
& PRV & 2.087 & $1.403^{* * *}$ & & & & & \\
& SYA & 2.182 & $0.911^{* * *}$ & & & & & \\
& ESAT1 & 2.249 & $0.810^{* * *}$ & 0.910 & 0.911 & 0.910 & 0.717 & 0.847 \\
Attitudinal Loyalty & ESAT2 & 3.205 & $0.841^{* * *}$ & & & & & \\
& ESAT3 & 3.505 & $0.869^{* * *}$ & & & & & \\
& ESAT4 & 2.985 & $0.866^{* * *}$ & & & & & \\
& ATT1 & 2.297 & $0.840^{* * *}$ & 0.873 & 0.878 & 0.875 & 0.636 & 0.797 \\
& ATT2 & 2.771 & $0.852^{* * *}$ & & & & & \\
Behavioural Loyalty & ATT3 & 2.280 & $0.762^{* * *}$ & & & & & \\
& ATT4 & 1.731 & $0.730^{* * *}$ & & & & & \\
& BEH1 & 1.463 & $0.703^{* * *}$ & 0.839 & 0.843 & 0.839 & 0.567 & 0.753 \\
& BEH2 & 2.127 & $0.735^{* * *}$ & & & & & \\
& BEH3 & 2.741 & $0.741^{* * *}$ & & & & & \\
& BEH4 & 1.904 & $0.828^{* * *}$ & & & & & \\
\hline
\end{tabular}

Source: Author research, 2020

This study uses the Cronbach's alpha $(\alpha)$ method and composite reliability (CR) to test whether the construct has good reliability. Meanwhile, the average variance extracted (AVE) and square root average variance extracted $(\sqrt{ } \mathrm{AVE})$ methods were used in the validity test. The test 
output results show AVE's value (0.553 to 0.737) and $\sqrt{\text { AVE }}(0.744$ to 0.858$)$. It can be concluded that the output validity is in accordance with the recommendations of Hair et al. (2014), so the overall constructs in this study are valid (AVE $>0.50$, VAVE $>0.70$, Loadings $>0.70$ ). Furthermore, the reliability output was measured using $\alpha$ and CR $(>0.70)$, according to the recommendations of Hair et al. (2014): Nunnally \& Bernstein (1994). The measurement results show that the overall research instrument is reliable (see Table 2).

\section{Structural Models}

After the required assumptions are fulfilled, the structural model is tested using $t$-values and $p$ values $(t=>1.96$ and $p=<0.05)$ according to the recommendations of Hair et al. (2010). Furthermore, this study used a 5,000 bias-corrected confidence interval with $p$-value for a twotailed significance (* p: 0.05, ** p: 0.01, *** p: 0.001) approach. Based on the results of the analysis shows (direct effect); E-S-Qual has a significant positive effect on attitudinal loyalty $(t=2.215, p=$ $<0.05)$, E-S-Qual has a significant positive effect on behavioral loyalty $(t=3.571, p=<0.05)$, ES-Qual has a significant positive effect on e-satisfaction $(t=19.025, p=<0.05)$, e-satisfaction has a significant positive effect on attitudinal loyalty $(t=7.258, p=<0.05)$, e-satisfaction has a significant positive effect on behavioral loyalty $(t=6.193, p=<0.05)$.

Table 3. The Output of Structural Models

\begin{tabular}{lcccc}
\hline \multicolumn{1}{c}{ Hypothesis } & $\beta$ & $t$-values & $p$-values & $95 \%$ BCCI \\
\hline E-S-Qual $\rightarrow$ Attitudinal Loyalty & 0.220 & 2.215 & 0.027 & $(0.043,0.434)$ \\
E-S-Qual $\rightarrow$ Behavioural Loyalty & 0.335 & 3.571 & 0.000 & $(0.159,0.532)$ \\
E-S-Qual $\rightarrow$ E-Satisfaction & 0.782 & 19.025 & 0.000 & $(0.691,0.851)$ \\
E-Satisfaction $\rightarrow$ Attitudinal Loyalty & 0.694 & 7.258 & 0.000 & $(0.482,0.868)$ \\
E-Satisfaction $\rightarrow$ Behavioural Loyalty & 0.589 & 6.193 & 0.000 & $(0.387,0.761)$ \\
E-S-Qual $\rightarrow$ E-Satisfaction $\rightarrow$ Attitudinal Loyalty & 0.543 & 7.116 & 0.000 & $(0.395,0.691)$ \\
E-S-Qual $\rightarrow$ E-Satisfaction $\rightarrow$ Behavioural Loyalty & 0.460 & 6.017 & 0.000 & $(0.313,0.617)$ \\
\hline
\end{tabular}

Source: Author research, 2020

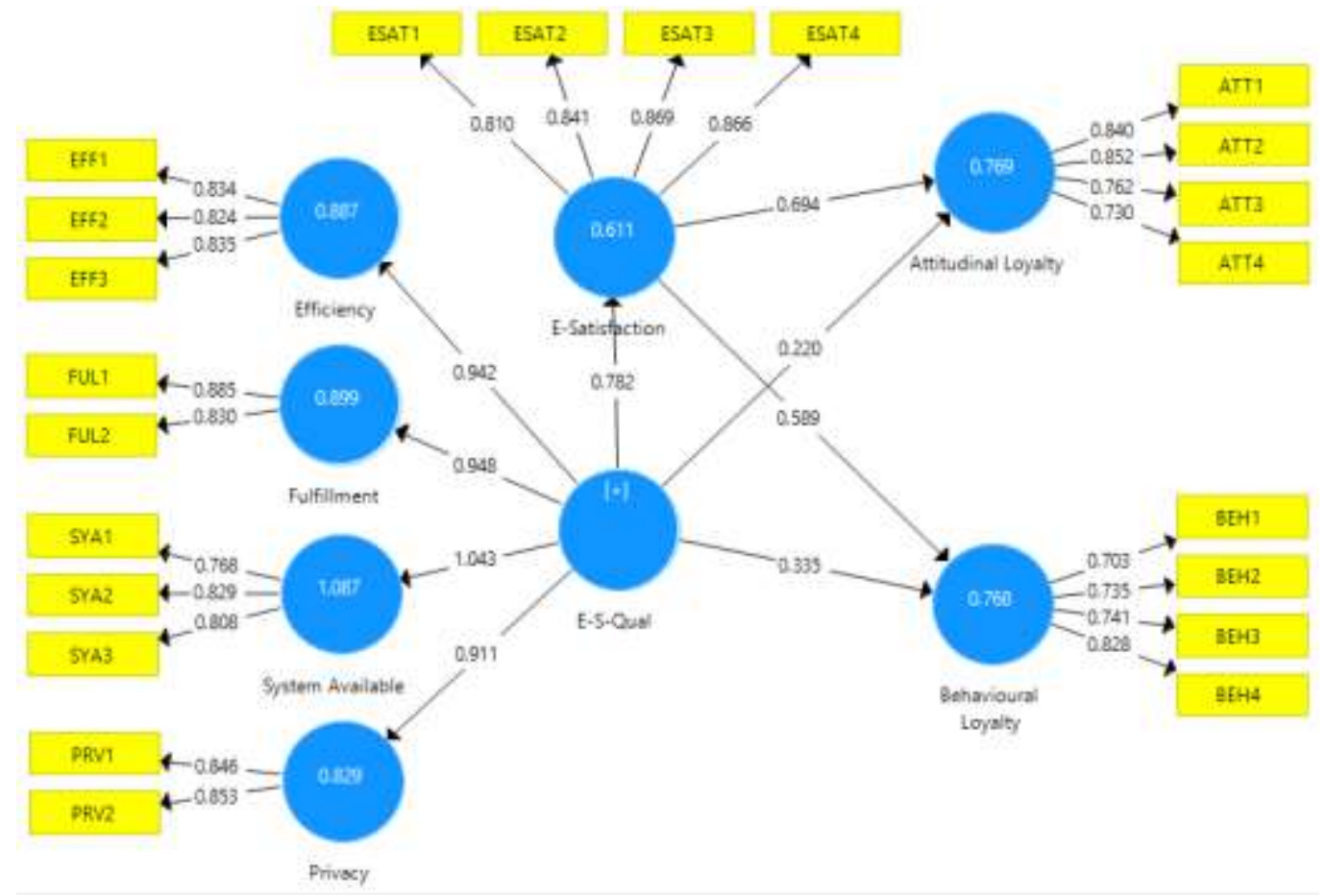

Source: Author research, 2020

Figure 2. Output of Path Analysis 
In the indirect effect specific test, the output analysis shows that e-satisfaction partially moderates the relationship between e-satisfaction and attitudinal loyalty. This is because the test results of the direct effect of ES-Qual on attitudinal loyalty showed significant positive results $(t=$ $2.215, p=<0.05)$, while the indirect effect also showed significant positive results $(t=7.116, p=$ $<0.05)$. Furthermore, the output analysis shows that e-satisfaction partially moderates the relationship between e-satisfaction with behavioral loyalty. This is because the test results of the direct effect of E-S-Qual on attitudinal loyalty showed significant positive results $(t=3.571, p=<$ $0.05)$, while the indirect effect also showed significant positive results $(t=6.193, p=<0.05)$.

Table 4. Output Total Effect

\begin{tabular}{lcccc}
\hline & $\beta$ & $t$-values & p-values & $95 \%$ BCCI \\
\hline E-S-Qual $\rightarrow$ Attitudinal Loyalty & 0.762 & 15.111 & 0.000 & $(0.651,0.849)$ \\
E-S-Qual $\rightarrow$ Behavioural Loyalty & 0.796 & 18.473 & 0.000 & $(0.701,0.870)$ \\
E-S-Qual $\rightarrow$ E-Satisfaction & 0.782 & 19.025 & 0.000 & $(0.691,0.851)$ \\
E-Satisfaction $\rightarrow$ Attitudinal Loyalty & 0.694 & 7.258 & 0.000 & $(0.482,0.863)$ \\
E-Satisfaction $\rightarrow$ Behavioural Loyalty & 0.589 & 6.193 & 0.000 & $(0.387,0.761)$ \\
\hline
\end{tabular}

Source: Author research, 2020

Table 5. $R^{2}$ Output

\begin{tabular}{lcc}
\hline & R Square & R Square Adjusted \\
\hline Attitudinal Loyalty & 0.769 & 0.767 \\
Behavioural Loyalty & 0.768 & 0.766 \\
E-Satisfaction & 0.611 & 0.609 \\
\hline
\end{tabular}

Source: Author research, 2020

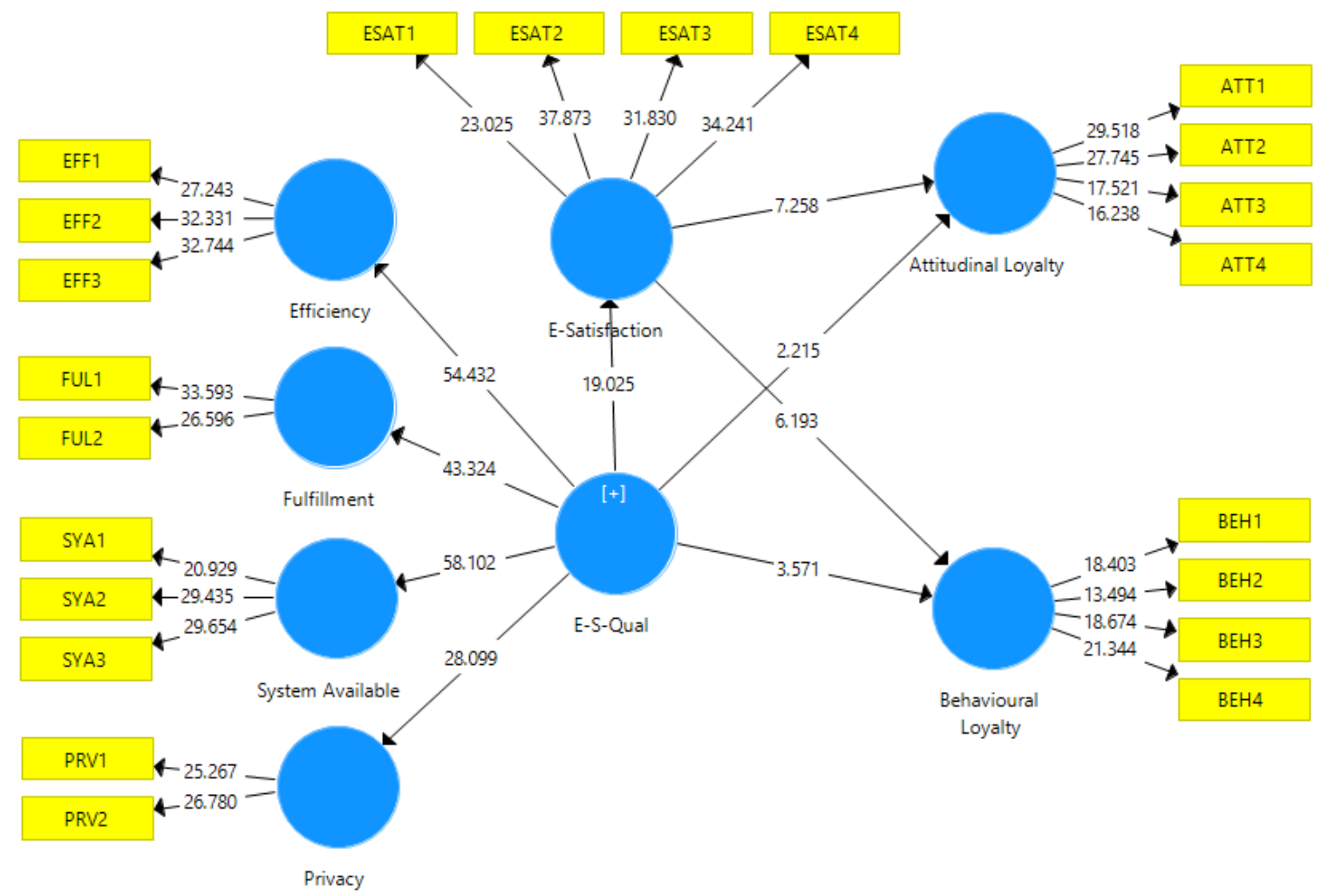

Source: Author research, 2020

Figure 3. Output of Bootstrapping Analysis 
Table 6. $f^{2}$ Output

\begin{tabular}{lccc}
\hline & Attitudinal Loyalty & Behavioural Loyalty & E-Satisfaction \\
\hline E-S-Qual & 0.081 & 0.189 & 1.570 \\
E-Satisfaction & 0.811 & 0.581 & \\
\hline
\end{tabular}

Table 7. Blindfolding Output

\begin{tabular}{lccc}
\hline & SSO & SSE & $Q^{2}$ \\
\hline Attitudinal Loyalty & 1092 & 595.5 & 0.455 \\
Behavioural Loyalty & 1092 & 652.0 & 0.403 \\
E-Satisfaction & 1092 & 655.9 & 0.399 \\
E-S-Qual & 2730 & 2730 & - \\
\hline
\end{tabular}

Source: Author research, 2020

\section{Discussion}

Overall the hypotheses in this study are fulfilled and consistent with previous studies. The results of hypotheses 1 and 2 show that m-banking service quality has a positive and significant effect on attitudinal and behavioral loyalty. These findings support the previous empirical results, which state that most mobile banking users assess service quality based on the relative benefits obtained. The increasingly high quality of mobile banking services has implications for customer loyalty, both attitude and behavior (Yang \& Tsai, 2007; Asgari et al., 2014; Nisha, 2016). Furthermore, the results of hypotheses 3 and 4 can be concluded that e-satisfaction mediates the relationship between $\mathrm{m}$ banking service quality on attitudinal loyalty and behavioral loyalty. These findings can be explained that the higher the quality of electronic services is closely related to how satisfaction is created, with the presence of satisfaction intermediaries, then customer loyalty can immediately emerge from the bottom of the customer's heart without coercion from any party (Arcand et al., 2017; Saibil, 2020; Sathiyavany \& Shivany, 2018).

The next results refer to hypothesis 5 . Empirical findings show that $\mathrm{m}$-banking service quality has a significant positive effect on e-satisfaction. These findings support previous results, which state that the higher the perception of value obtained by customers from electronic banking services, the more satisfied the customer be (Quan, 2010; Sundaram et al., 2017; Zavareh et al., 2012). Finally, the results of hypotheses 6 and 7 show that e-satisfaction has a significant positive effect on both behavioral and attitudinal loyalty. These results lead to the creation of customer satisfaction in instant electronic transactions, which have implications for creating customer loyalty both in terms of behavior and attitude (Aisyah, 2018; Dandis \& Wright, 2020; Sathiyavany \& Shivany, 2018).

\section{Conclusion and Implications}

The results of empirical research underline that the majority of mobile banking users in Islamic banking assess service quality based on the relative benefits obtained. The higher mobile banking service quality has implications for customer loyalty, both attitude and behavior. This is done when the customer is satisfied with the quality of the system displayed. This satisfaction can be achieved if the dimensions of quality that are characteristic of the system can be presented by Islamic banking. This study also underscores the dimensions of efficiency and system availability as the keys to mobile banking service quality. Efficiency refers to how the system's ease, accessibility, and speed can facilitate transactions and other functions. Furthermore, system availability refers to how the platforms function properly about technical constraints that may arise and attachment to functions that strengthen processes in the business of Islamic banking customers.

For this reason, Islamic banking must always maintain the functions of their mobile banking services, such as; easy access, functions appropriately, protects customer privacy, resolves 
transaction errors, and provides assistance if an error occurs. In addition, banks must actively inform their customers about the process and time required for certain services under the mobile banking system to reduce customer complaints and ensure quality information. The better the quality of service provided by Islamic banks through the mobile banking platform, the higher customer satisfaction will be and in the end, will result in customer loyalty, both behavior and attitude.

\section{References}

Aisyah, M. (2018). Islamic Bank Service Quality and Its Impact on Indonesian Customers' Satisfaction and Loyalty. Al-Iqtishad: Jurnal Ilmu Ekonomi Syariah, 10(2). https://doi.org/10.15408/aiq.v10i2.7135

Amin, M. (2016). Internet banking service quality and its implication on e-customer satisfaction and e-customer loyalty. International Journal of Bank Marketing, 34(3), 280-306. https://doi.org/10.1108/IJBM-10-2014-0139

Anderson, R. E., \& Srinivasan, S. S. (2003). E-Satisfaction and E-Loyalty: A Contingency Framework. Psychology and Marketing, 20(2), 123-138. https://doi.org/10.1002/mar.10063

Anwar, M., Rehman, A.U. and Shah, S.Z.A. (2018), Networking and new venture's performance: mediating role of competitive advantage. International Journal of Emerging Markets, 13(5), 998 1025. https://doi.org/10.1108/IJoEM-07-2017-0263

Arcand, M., PromTep, S., Brun, I., \& Rajaobelina, L. (2017). Mobile banking service quality and customer relationships. International Journal of Bank Marketing, 35(7), 1068-1089. https://doi.org/10.1108/IJBM-10-2015-0150

Ariff, M. S. M., Yun, L. O., Zakuan, N., \& Ismail, and K. (2014). The Impacts of e-Service Quality and e-Customer Satisfaction on e-Customer Loyalty in Internet Banking. Advanced Science Letters, 20(1), 285-289. https://doi.org/10.1166/asl.2014.5260

Asgari, N., Ahmadi, M. H., Shamlou, M., Rashid Farokhi, A., \& Farzin, M. (2014). Studying the Impact of E-Service Quality on E-Loyalty of Customers in the Area of E-Banking Services. Journal of Management and Sustainability, 4(2), 126-133. https://doi.org/10.5539/jms.v4n2p126

Banerjee, N., \& Sah, S. (2012). A Comparative Study of Customers' Perceptions of Service Quality Dimensions between Public and Private Banks in India. International Journal of Business Administration, 3(5), 33-44. https://doi.org/10.5430/ijba.v3n5p33

Cahaya, Y. F., \& Siswanti, I. (2020). Internet Banking Service Quality in Indonesia and Its Impact on E-Customer Satisfaction and E-Customer Loyalty. Management Research Studies Journal, I(1), 75-83. http://journal.perbanas.id/index.php/mrsj/article/view/350

Chowdhury, I. A., Othman, A. S., Bo, Y., \& Huey, L. Y. (2017). Driving force of e-loyalty in online banking sector in the context of Malaysia. People: International Journal of Social Sciences, 3(3), 43-65. https://doi.org/10.20319/pijss.2017.33.4365

Dandis, A. O., \& Wright, L. T. (2020). The effects of CARTER model on attitudinal loyalty in Islamic banks. International Journal of Quality and Service Sciences, 12(2), 149-171. https://doi.org/10.1108/IJQSS-03-2019-0050

Fraering, M., \& Minor, M. S. (2013). Beyond loyalty: Customer satisfaction, loyalty, and fortitude. Journal of Services Marketing, 27(4), 334-344. https://doi.org/10.1108/08876041311330807

Fragata, A., \& Moustakas, E. (2013). Investigating the Determinants of e-Banking Loyalty for Large Business Customers: Two Empirical Models. Journal of Economics, Business and Management, 
1(2), 204-208. https://doi.org/10.7763/JOEBM.2013.V1.44

Gefen, D. (2002). Customer Loyalty in E-Commerce. Journal of the Association for Information Systems, 3(1), 27-53. https://doi.org/10.17705/1jais.00022

Hair, J. F., Black, W. C., Babin, B. J., \& Anderson, R. E. (2010). Multivariate Data Analysis. In Vectors (p. 816). https://doi.org/10.1016/j.ijpharm.2011.02.019

Hair, J. F., Hult, T., Ringle, C., \& Sarstedt, M. (2014). A Primer on Partial Least Squares Structural Equation Modeling (PLS-SEM). Thousand Oaks, CA: Sage Publications, Inc.

Jun, M., \& Cai, S. (2001). The key determinants of Internet banking service quality: a content analysis. International Journal of Bank Marketing, 19(7), 276-291. https://doi.org/10.1108/02652320110409825

Kannan, P. K., Wagner, J., \& Velarde, C. (2002). Initiatives for Building e-Loyalty: A Proposed Framework and Research Issues. In E-Business Management (pp. 231-247). Kluwer Academic Publishers. https://doi.org/10.1007/0-306-47548-0_11

Nisha, N. (2016). Exploring the Dimensions of Mobile Banking Service Quality. International Journal of Business Analytics, 3(3), 60-76. https://doi.org/10.4018/IJBAN.2016070104

Nunnally, C, J., \& Bernstein, H, I. (1994). Psychometric Theory. McGraw-Hill.

Oliver, R. L. (1999). Whence Consumer Loyalty? Journal of Marketing, 63, 33. https://doi.org/10.2307/1252099

Omoregie, O. K., Addae, J. A., Coffie, S., Ampong, G. O. A., \& Ofori, K. S. (2019). Factors influencing consumer loyalty: evidence from the Ghanaian retail banking industry. International Journal of Bank Marketing, 37(3), 798-820. https://doi.org/10.1108/IJBM-042018-0099

Parasuraman, A., Zeithaml, V. A., \& Malhotra, A. (2005). E-S-QUAL. Journal of Service Research, 7(3), 213-233. https://doi.org/10.1177/1094670504271156

Quan, S. (2010). Assessing the Effects of e-Service Quality and e-Satisfaction on Internet Banking Loyalty in China. 2010 International Conference on E-Business and E-Government, 93-96. https://doi.org/10.1109/ICEE.2010.31

Raza, S. A., Shah, N., \& Ali, M. (2019). Acceptance of mobile banking in Islamic banks: evidence from modified UTAUT model. Journal of Islamic Marketing, 10(1), 357-376. https://doi.org/10.1108/JIMA-04-2017-0038

Raza, S. A., Umer, A., Qureshi, M. A., \& Dahri, A. S. (2020). Internet banking service quality, ecustomer satisfaction and loyalty: the modified e-SERVQUAL model. The TQM Journal, 32(6), 1443-1466. https://doi.org/10.1108/TQM-02-2020-0019

Riza, A. F. (2019). Customer acceptance of digital banking in Islamic bank: Study on millennial generation. Conference on Islamic Management Accounting and Economics, 2, 66-74. https://journal.uii.ac.id/CIMAE/article/view/13351

Riza, A.F. \& Hafizi, R. (2019). Customers Attitude Toward Islamic Mobile Banking in Indonesia: Implementation of TAM. Asian Journal of Islamic Management, 1(2), 75-84. DOI: 10.1108/AJIM.vol1.iss2.art1

Sachdev, S., \& Verma, H. (2004). Relative importance of service quality dimensions: a multisectoral study. Journal of Services Research, 4(1), 93.

Sagib, G. K., \& Zapan, B. (2014). Bangladeshi mobile banking service quality and customer satisfaction and loyalty. Management and Marketing, 9(3), 331-346. 
Saibil, D. I. (2020). Does The Banking Information System Affect Customer Satisfaction and Loyalty? EkBis: Jurnal Ekonomi dan Bisnis, 4(1), 353-364.

Sathiyavany, N., \& Shivany, S. (2018). E-Banking Service Qualities, E-Customer Satisfaction, and e-Loyalty: A conceptual Model. The International Journal of Social Sciences and Humanities Invention, 5(6), 4808-4819. https://doi.org/10.18535/ijsshi/v5i6.08

Shaikh, A. A., \& Karjaluoto, H. (2015). Mobile banking adoption: A literature review. Telematics and Informatics, 32(1), 129-142. https://doi.org/10.1016/j.tele.2014.05.003

Sharma, G., \& Malviya, S. (2014). Exploring the Dimensions of Mobile Banking Service Quality. Review of Business and Technology Research, 2(1), 187-196.

Srinivasan, S. S., Anderson, R., \& Ponnavolu, K. (2002). Customer loyalty in e-commerce: an exploration of its antecedents and consequences. Journal of Retailing, 78(1), 41-50. https://doi.org/10.1016/S0022-4359(01)00065-3

Sundaram, V., Ramkumar, D., \& Shankar, P. (2017). Impact of E-Service Quality on Customer Satisfaction and Loyalty Empirical Study in India Online Business. KINERJA, $21(1), 48$. https://doi.org/10.24002/kinerja.v21i1.1034

Swaminathan, S., Anderson, R., \& Song, L. (2018). Building loyalty in e-commerce: Impact of business and customer characteristics. Journal of Marketing Channels, 25(1-2), 22-35. https://doi.org/10.1080/1046669X.2019.1646184

Thakur, R., \& Srivastava, M. (2014). Adoption readiness, personal innovativeness, perceived risk and usage intention across customer groups for mobile payment services in India. Internet Research, 24(3), 369-392. https://doi.org/10.1108/IntR-12-2012-0244

Tumewah, E., Juniarta, J., \& Kurniawan, Y. (2020). The Effect of M-Banking Service Quality and Customer Perceived Value to Satisfaction and Loyalty of Bank XYZ Customers. International Journal of Management and Humanities, 4(6), 132-138. https://doi.org/10.35940/ijmh.F0634.024620

Westbrook, R. A., \& Reilly, M. D. (1983). Value-Percept Disparity: an Alternative to the Disconfirmation of Expectations Theory of Consumer Satisfaction. Advances in Consumer Research, 10, 256-261.

Yang, H., \& Feng-Shii Tsai. (2007). General E-S-QUAL Scales Applied to Websites Satisfaction and Loyalty Model. Communications of the IIMA, 7(2), 115-126. http://www.iima.org/CIIMA/15 CIIMA 7-2-07 Yang-Tsai 115-126.pdf

Yuan, S., Liu, Y., Yao, R., \& Liu, J. (2016). An investigation of users' continuance intention towards mobile banking in China. Information Development, 32(1), 20-34. https://doi.org/10.1177/0266666914522140

Zavareh, F. B., Ariff, M. S. M., Jusoh, A., Zakuan, N., Bahari, A. Z., \& Ashourian, M. (2012). EService Quality Dimensions and Their Effects on E-Customer Satisfaction in Internet Banking Services. Procedia - Social and Behavioral Sciences, 40, 441-445. https://doi.org/10.1016/j.sbspro.2012.03.213 